\title{
Article \\ Antibacterial Profile of a Microbicidal Agent Targeting Tyrosine Phosphatases and Redox Thiols, Novel Drug Targets
}

\author{
Kylie White *(1), Gina Nicoletti and Hugh Cornell \\ STEM College, RMIT University, Melbourne, VIC 3001, Australia; ambrogina.nicoletti@rmit.edu.au (G.N.); \\ humarg1@hotmail.com (H.C.) \\ * Correspondence: kylie.white3@rmit.edu.au
}

Citation: White, K.; Nicoletti, G. Cornell, H. Antibacterial Profile of a Microbicidal Agent Targeting Tyrosine Phosphatases and Redox Thiols, Novel Drug Targets. Antibiotics 2021, 10, 1310. https:// doi.org/10.3390/antibiotics10111310

Academic Editors: Nicholas Dixon and Marc Maresca

Received: 12 September 2021

Accepted: 24 October 2021

Published: 27 October 2021

Publisher's Note: MDPI stays neutral with regard to jurisdictional claims in published maps and institutional affiliations.

Copyright: (c) 2021 by the authors. Licensee MDPI, Basel, Switzerland. This article is an open access article distributed under the terms and conditions of the Creative Commons Attribution (CC BY) license (https:// creativecommons.org/licenses/by/ $4.0 /)$.

\begin{abstract}
The activity profile of a protein tyrosine phosphatase (PTP) inhibitor and redox thiol oxidant, nitropropenyl benzodioxole (NPBD), was investigated across a broad range of bacterial species. In vitro assays assessed inhibitory and lethal activity patterns, the induction of drug variants on long term exposure, the inhibitory interactions of NPBD with antibiotics, and the effect of plasma proteins and redox thiols on activity. A literature review indicates the complexity of PTP and redox signaling and suggests likely metabolic targets. NPBD was broadly bactericidal to pathogens of the skin, respiratory, urogenital and intestinal tracts. It was effective against antibiotic resistant strains and slowly replicating and dormant cells. NPBD did not induce resistant or drug-tolerant phenotypes and showed low cross reactivity with antibiotics in synergy assays. Binding to plasma proteins indicated lowered in-vitro bioavailability and reduction of bactericidal activity in the presence of thiols confirmed the contribution of thiol oxidation and oxidative stress to lethality. This report presents a broad evaluation of the antibacterial effect of PTP inhibition and redox thiol oxidation, illustrates the functional diversity of bacterial PTPs and redox thiols, and supports their consideration as novel targets for antimicrobial drug development. NPBD is a dual mechanism agent with an activity profile which supports consideration of tyrosine phosphatases and bacterial antioxidant systems as promising targets for drug development.
\end{abstract}

Keywords: antimicrobial; nitropropenyl benzodioxole; nitroalkenyl benzenes; tyrosine signaling; protein tyrosine phosphatase inhibitor; thiol oxidant; redox signaling; drug target

\section{Introduction}

Cellular signal transduction networks sense and transmit internal and external signals, resulting in coordinated responses to stimuli. Reversible phosphorylation on serine (Ser), threonine (Thr) and tyrosine (Tyr) residues in proteins is a major post translational modification that regulates signal-transduction and protein functions in cellular physiological processes [1]. Bacterial regulatory networks of kinases phosphatases are complex and interconnected and enable adaptation to the challenges of stressful and changing environments. Coordination between activating kinases, which control the amplitude of a signal response, and terminating phosphatases, which control response rate and duration, maintain cell homeostasis [2]. Protein tyrosine kinases (PTKs) and protein tyrosine phosphatases (PTPs) are important regulators of signaling events and are widely and heterogeneously distributed across eukaryotic and prokaryotic cells [3]. Bacterial PTKs and PTPs have diversified structurally and functionally from those in eukaryotes, performing differing and often unique functions making them suitable targets for selective inhibition [3].

Bacteria have unique auto-phosphorylating tyrosine kinases (BY-Ks) which govern metabolic functions including the cell cycle, DNA metabolism, transcription and gene expression. BY-Ks have relaxed substrate specificity, phosphorylate multiple proteins and are suited for adaptation to new environments. Bacteria have eukaryotic-type serine and threonine kinases (eSTK), that can phosphorylate on tyrosine and cross-phosphorylate with BY-ks [4]. 
Cysteine-dependent PTPs belong to structurally and functionally diverse families that share an essential and invariant cysteine residue in the catalytic motif. PTPs are classified by sequence differences in the catalytic and flanking domains which determine substrate specificity and enzyme functionality [2]. PTPs include tyrosine-specific PTPs (sPTP), low molecular weight PTP (LMWPTP) and dual-specific phosphatases (DSP) which can dephosphorylate Ser, Thr and Tyr residues. LMWPTPs, predominant in bacteria, are concerned with BY-K modulation and have a more diverse range of functions than eukaryotic LMWPTP [3].

Catalytic cysteine thiolates are highly susceptible to transient, reversible oxidation by nucleophiles and electrophiles which inactivate phosphatase function, and to reduction by cellular redox thiols and reductases, which restore function, ensuring efficient enzyme recycling. Redox regulation of PTPs indirectly regulates PTK signaling, PTP activation terminating, inactivation prolonging, and tyrosine signaling. Oxidation of non-catalytic cysteine residues in PTKs and PTPs also regulates their activity $[5,6]$. Reactive oxygen species (ROS) transiently oxidize and inactivate PTPs and other cysteine-dependent enzymes. Low molecular weight redox active thiols (LMWT) and enzymes such as thioredoxins and glutaredoxins play major roles in reversing the oxidative inactivation of enzymes, maintaining a reduced cytoplasm [7].

Phosphotyrosine (PTyr) proteins vary greatly in abundance in bacterial species and are involved in nucleotide metabolism, transcription, cell integrity, synthesis and transport of extracellular polysaccharides, stress responses and virulence activities [8,9]. Many bacterial PTPs are identified genomically or have functions inferred from homology with characterized PTPs. Their effects are largely identified by phenotypic changes in null mutants or chemically suppressed cells. Suppression by PTP inhibitors is often the first indication that PTPs play a role in a physiological function. PTPs positively and negatively regulate components of signal pathways and their inhibition could result in desirable or undesirable physiological effects, which might differ between species. They are present at very low levels and are transiently and variably active, depending on the environmental context, making identification of functions difficult [10].

Nitropropenyl benzodioxole (NPBD) is a lipophilic, cell permeable, neutral tyrosine mimetic, belonging to the family of nitroalkenyl benzenes (NAB) (Figure 1; Supplementary Materials Figure S1 and Table S1). Nitroethenyl benzene (NEB), nitropropenyl benzene (NPB), nitroethenyl benzodioxole and NPBD are reversible inhibitors of enzymatic activity of PTP1B, SHP1, Yop and CD45 with differing levels of inhibition of enzymatic function ([11-13], Table S2). These compounds compete with PTyr substrate proteins for binding to PTP active sites. The electrophilic nitropropenyl and nitroethenyl substituents inhibit enzyme function through oxidation of the cysteine residue. The presence of mercaptoethanol strongly reduces NAB inhibition of enzymatic activity of PTP1B and SHP1 [11]. $\mathrm{NABs}$ are strong electrophiles and oxidants and readily undergo reduction by reversible Michael addition of nucleophilic thiolates [14]. Depletion of the redox thiol pool, which maintains a reduced cytoplasm and cytosol, results in increased levels of redox-reactive species and increased oxidative stress (OS), contributing to cell death [7]. Conversely, thiol reduction of the nitroalkene moiety of NABs suppresses antimicrobial activity, the nitro alkane substituted NABs being inactive $[15,16]$.

$\mathrm{NAB}$ analogues with varied benzene substituents show different activity patterns for bacteria and fungi and different zebrafish embryogenic toxicities, indicating the significance of substituents on the benzene ring for substrate selectivity [3]. NPBD $0.2 \mathrm{mg} / \mathrm{L}$ inhibits zebrafish egg hatching and in embryos reduces the heartbeat rate and affects epiboly movement and eye development in a dose-dependent manner but does not cause morphological abnormalities [15]. Many antibiotics $(0.001-0.2 \mathrm{mg} / \mathrm{L})$ show a variety of toxic effects on zebrafish development and metabolism [17]. Zebrafish toxicity was not predictive of oral animal toxicity. NPBD has low oral toxicity and low absorption from oral administration in rodents and is well tolerated on IV administration ([15]; Supplementary Materials Tables S3 and S4, Figure S2). NPBD is a broad-spectrum agent. It is fungicidal, 
inhibits unicellular protozoan pathogens in vitro and in vivo ([15], Nicoletti unpublished data) and is selectively toxic to lung cancer cells ([18], Table S5). NPBD (BDM-I), a broadly active $\mathrm{NAB}$ analogue, is in preclinical development as an antimicrobial drug for human therapeutic uses by Opal Biosciences Ltd.

(a)<smiles>C/C(=C\c1ccc2c(c1)OCO2)[N+](=O)[O-]</smiles>

(c)<smiles>C/C(=C\c1ccccc1)[N+](=O)[O-]</smiles>

(b)<smiles>O=[N+]([O-])C=Cc1ccccc1</smiles>

(d)<smiles>N[C@@H](Cc1ccc(O)cc1)C(=O)O</smiles>

Figure 1. Structural similarity of PTP inhibitors (a) NPBD (5-(2-nitroprop-1-enyl)-1,3-benzodioxole), (b) NEB, (2-nitroethenylbenzene), and (c) NPB (2-nitroprop-1-enylbenzene) to (d) Tyrosine, ((2S)-2amino-3-(4-hydroxyphenyl)propanoic acid).

We report here on the activity profile of NPBD against phylogenetically diverse bacterial species, providing a broad-spectrum evaluation of a selective PTP inhibitor which highlights the diversity of PTP functions in bacterial physiology, and identifying possible PTP targets in bacterial species. The report supports the proposal that tyrosine phosphatases and redox thiols are potential bacterial drug targets.

\section{Results and Discussion}

\subsection{NPBD Is Broadly Active against Clinically Significant Bacterial Species}

The MIC and MBC of NPBD and positive control Ciprofloxacin were determined across 11 orders comprising 16 families and 39 species (Table 1, Table S6). The grouping of species by phylogenetic types facilitated detection of different activity patterns related to evolutionary diversity in structure and function.

Table 1. Antibacterial activity of NPBD against clinically significant species.

\begin{tabular}{|c|c|c|c|c|}
\hline Phylum $^{\text {a }}$ & & & & \\
\hline \multicolumn{5}{|l|}{ Order (Family) } \\
\hline Species & $\mathrm{MIC}_{100}{ }^{\mathrm{b}}$ & $\pm \mathrm{SD}$ & $\mathrm{MBC}_{99.9}{ }^{\mathrm{b}}$ & $\pm \mathbf{S D}$ \\
\hline \multicolumn{5}{|l|}{ Firmicutes/Actinobacteria (Gram-positive) } \\
\hline \multicolumn{5}{|l|}{ Bacillales (Bacillaceae) } \\
\hline Bacillus subtilis ATCC6633 & 8 & 0 & 16 & 0 \\
\hline B. cereus RMIT $30 / 7$ & 9.2 & 6.6 & 12.1 & 4.4 \\
\hline Enterococcus faecalis ATCC 29212 * & 16 & 0 & $>512$ & \\
\hline E. faecalis antibiotic resistant clinical strains (7) & 16 & 0 & $>512$ & \\
\hline E. faecium VRE 345/19-1 \& VRE/19 & 25.4 & 9.2 & $>512$ & \\
\hline \multicolumn{5}{|l|}{ Bacillales (Staphylococcaeae) } \\
\hline Staphylococcus aureus ATCC 29213 * & 4.8 & 1.9 & $\geq 512$ & \\
\hline S. aureus antibiotic resistant clinical strains (12) & 5.0 & 1.9 & $\geq 512$ & \\
\hline S. epidermidis ATCC 35984 & 5.0 & 2 & $\geq 512$ & \\
\hline \multicolumn{5}{|l|}{ Lactobacillalles (Streptococcceae) } \\
\hline Streptococcus pneumoniae ATCC 49619 * & 16.0 & 0 & 32 & 0 \\
\hline S. pyogenes ATCC 19615 & 2.8 & 1.2 & 5.7 & 2.3 \\
\hline S. pyogenes clinical strains (10) & 2.7 & 1 & 3.4 & 0.85 \\
\hline
\end{tabular}


Table 1. Cont.

\begin{tabular}{|c|c|c|c|c|}
\hline Phylum ${ }^{a}$ & & & & \\
\hline \multicolumn{5}{|l|}{ Order (Family) } \\
\hline Species & $\mathrm{MIC}_{100} \mathrm{~b}$ & $\pm \mathrm{SD}$ & $\mathrm{MBC}_{99.9} \mathrm{~b}$ & $\pm \mathrm{SD}$ \\
\hline \multicolumn{5}{|l|}{ Lactobacillalles (Lactobacillaceae) } \\
\hline Lactobacillus casei RMIT 190/3 & 49 & 21.5 & 338 & 200 \\
\hline \multicolumn{5}{|l|}{ Clostridiales (Peptostreptococcaceae) } \\
\hline $\begin{array}{l}\text { Clostridium difficile ATCC } 9689 \text { (Clostridiodes } \\
\text { difficile, Peptoclostridium difficile) }\end{array}$ & 8 & 0 & 16 & 0 \\
\hline C. difficile (Clinical isolate) & 6 & 2 & 10 & 5 \\
\hline \multicolumn{5}{|l|}{ Clostridiales (Clostridiaceae) } \\
\hline C. perfringens NCTC 8237 & 5 & 2 & 10 & 5 \\
\hline C. sporogenes RMIT 52/4 & 1 & 0 & 1 & 0 \\
\hline C. tetani RMIT $52 / 5$ & 1 & 0 & 1 & 0 \\
\hline \multicolumn{5}{|l|}{ Corynebacteriales (Corynebacteriaceae) } \\
\hline Corynebacterium xerosis RMIT53/5 & 8 & 0 & 16 & 0 \\
\hline Average & 10.5 & 4.7 & 281.6 & 40.9 \\
\hline \multicolumn{5}{|c|}{ Proteobacteria $(\alpha, \beta, \gamma)$ (Gram-negative, non-enteric, lipo-oligosaccharide) } \\
\hline \multicolumn{5}{|l|}{ Pasteurellales (Pasteurellaceae) } \\
\hline Haemophilus influenzae $(\gamma)$ ATCC 49247 & 0.125 & 0 & 0.125 & 0 \\
\hline Pasteurella multocida $(\gamma)$ RMIT 284/1-2 & 2.2 & 0.8 & 3.2 & 1.0 \\
\hline \multicolumn{5}{|l|}{ Neisseriales (Neisseriaceae) } \\
\hline Neisseria gonorrhoeae ( $\beta$ ) RMIT $240 / 2$ & 5 & 2.3 & 5 & 2.3 \\
\hline N. gonorrhoeae WHO strain VI & 2 & 0 & 2 & 0 \\
\hline N. meningitidis ATCC 13090 & 0.5 & 0 & 0.5 & 0 \\
\hline \multicolumn{5}{|l|}{ Rhizobiales (Brucellaceae) } \\
\hline Brucella abortus ( $\alpha$ ) RMIT 33/1 $48 \mathrm{~h}$ & 42 & 17 & 76 & 32 \\
\hline \multicolumn{5}{|l|}{ Pseudomonadales (Moraxellaceae) } \\
\hline $\begin{array}{l}\text { Acinetobacter calcoaceticus var. anitratus }(\gamma) \\
\text { RMIT3131 }\end{array}$ & 128 & 0 & 256 & 0 \\
\hline Moraxella catarrhalis $(\gamma)$ RMIT $211 / 2$ & 16 & 0 & 32 & 0 \\
\hline Average & 24.5 & 4.9 & 46.8 & 8.9 \\
\hline \multicolumn{5}{|c|}{ Proteobacteria $(\gamma, \varepsilon)($ Gram-negative, enteric, lipo-oligosaccharide) } \\
\hline \multicolumn{5}{|l|}{ Campylobacteriales (Campylobactereaceae) } \\
\hline Campylobacter jejuni $(\delta / \varepsilon)$ ATCC $43446(0: 19)$ & 202 & 74 & 323 & 148 \\
\hline C. jejuni NCTC11168 & 203 & 66.1 & 431 & 128 \\
\hline C. jejuni $54 / 1-2$ & 203 & 66 & 431 & 128 \\
\hline C. jejuni 331 & 161 & 73.9 & 362 & 181 \\
\hline C. jejuni antibiotic resistant strain (6) & 276 & 82.79 & 424 & 171 \\
\hline C. coli & 202 & 74 & 406 & 148 \\
\hline C. laridis & 128 & 0 & 256 & 0 \\
\hline C. sputorum & 128 & 0 & 256 & 0 \\
\hline C. foetus & 203 & 74 & 512 & 0 \\
\hline C. hyointestinalis & 128 & 0 & 256 & 0 \\
\hline Average & 183.5 & 33.73 & 365.6 & 75.4 \\
\hline \multicolumn{5}{|l|}{ Bacteroidales (Bacteriodaceae) } \\
\hline Bacteroides fragilis NCTC9343 & 23 & 14 & 39 & 16 \\
\hline \multicolumn{5}{|l|}{ Enterobacterales (Yersiniaceae) } \\
\hline Yersinia enterocolitica $(\gamma)$ ATCC 23715 & 16 & 0 & 32 & \\
\hline Y. enterocolitica ATCC 70020 & 16 & 0 & 32 & \\
\hline Average & 18.3 & 5.90 & 34.3 & 14.3 \\
\hline
\end{tabular}


Table 1. Cont.

\begin{tabular}{|c|c|c|c|c|}
\hline Phylum a & & & & \\
\hline \multicolumn{5}{|l|}{ Order (Family) } \\
\hline Species & $\mathrm{MIC}_{100} \mathrm{~b}$ & $\pm S D$ & $\mathrm{MBC}_{99.9}{ }^{\mathrm{b}}$ & $\pm \mathrm{SD}$ \\
\hline \multicolumn{5}{|c|}{ Proteobacteria $(\gamma)$ (Gram-negative, enteric, lipopolysaccharide) } \\
\hline \multicolumn{5}{|l|}{ Enterobacterales (Morganellaceae) } \\
\hline Proteus mirabilis RMIT 281/1 & 180 & 74 & $>512^{\mathrm{c}}$ & \\
\hline P. mirabilis clinical strains (6) & 64 & 0 & $>512$ & \\
\hline P. vulgaris RMIT $281 / 3$ & 53 & 16 & 181 & 73 \\
\hline P. vulgaris ATCC13315 & 8 & 0 & 25 & 9 \\
\hline Average & 76.3 & 30.44 & 103.0 & 36.8 \\
\hline \multicolumn{5}{|l|}{ Enterobacterales (Enterobacteriaceae) } \\
\hline Enterobacter aerogenes & 512 & & $\geq 512^{\mathrm{c}}$ & \\
\hline Escherichia coli ATCC 27853 & 323 & 132.2 & $\geq 512^{c}$ & \\
\hline E. coli ATCC $25922 *$ & 512 & & $>512^{c}$ & \\
\hline E. coli RMIT 1110/1-5 (5) & $>512$ & & & \\
\hline Klebsiella aerogenes (Areobacter) ATCC 13048 & $>512$ & & $>512^{\mathrm{c}}$ & \\
\hline K. oxytoca RMIT $180 / 4$ & $\geq 512$ & & $>512^{c}$ & \\
\hline K. pneumoniae ATCC13833 & $\geq 512$ & & & \\
\hline K. pneumoniae RMIT 180/2-6 & $\geq 512$ & & & \\
\hline Salmonella Typhimurium ATCC 700720 & 512 & 0 & $>512^{c}$ & \\
\hline S. enterica Typhimurium ATCC14028 & 512 & & $>512^{c}$ & \\
\hline Serratia marcescens RMIT & $>512$ & & $>512^{c}$ & \\
\hline \multicolumn{5}{|l|}{ Pseudomonadales (Pseudomonadaceae) } \\
\hline Pseudomonas aeruginosa ATCC 27853 & $>512$ & & $>512^{c}$ & \\
\hline
\end{tabular}

a Phylogenetic taxonomy and nomenclature aligns with the National Center for Biotechnology Information (NCBI) for organisms in the public sequence databases. ${ }^{\mathrm{b}} \mathrm{MIC}_{100}$ and $\mathrm{MBC}_{99.9}$ by CLSI microdilution method (M11-A7; M07-A8) as appropriate for species from a minimum of three independent assays. Ciprofloxacin positive control MIC and MBC were within accepted ranges for QC control strains (*) (Table S6). Test systems contained 1\% v/v DMSO. ${ }^{c}$ MBC $\leq 2048 \mathrm{mg} / \mathrm{L}$ in presence of $\leq 5 \%$ DMSO. $24 \mathrm{~h}$ MIC/MBC except for Campylobacter spp. and Bacteroides sp. which were $48 \mathrm{~h}$. Geomean data for each species reported with average titres calculated for multiple strains of a species.

NPBD showed broad but variable activity against Gram-positive bacteria (average MIC $10.5 \pm 4.7 \mathrm{mg} / \mathrm{L}$, range $1-49 \mathrm{mg} / \mathrm{L})$, and was bactericidal at titres $\leq 2 \times$ MIC for all but staphylococci and enterococci. The Clostridiales, including $C$. difficile and $C$. perfringens, were the most susceptible (MIC range 1-8 mg/L). NPBD showed greater variability against Gram-negative pathogens, MIC titres ranging from 0.125 to $>512 \mathrm{mg} / \mathrm{L}$, however, all species, including those with MBC $>512 \mathrm{mg} / \mathrm{L}$, had bactericidal titres $\leq 4 \times \mathrm{MIC}$. Gramnegative species with lipo-oligosaccharide (LOS)-type cell envelopes colonizing non-enteric mucosal surfaces were generally susceptible $(24.5 \pm 4.9 \mathrm{mg} / \mathrm{L}$, range $0.125-128 \mathrm{mg} / \mathrm{L})$. Within this group, Pasteurella, Haemophilus and Neisseria were highly susceptible (average $1.9 \pm 1.9 \mathrm{mg} / \mathrm{L}$ ) and Brucella and Acinetobacter moderately susceptible (42 $\pm 17 \mathrm{mg} / \mathrm{L}$ and $128 \pm 0 \mathrm{mg} / \mathrm{L}$ respectively). The susceptibility of LOS-type enteric commensals varied. Ten species of Campylobacter had uniform MIC $(183 \pm 47 \mathrm{mg} / \mathrm{L})$ suggesting a corresponding uniformity in PTP targets. Y. enterocolitica $(16 \pm 0 \mathrm{mg} / \mathrm{L})$ and Bacteroides fragilis $(23 \pm 14 \mathrm{mg} / \mathrm{L})$ were moderately susceptible. Proteus species (Morganellaceae) showed variability between strains $(76 \pm 30 \mathrm{mg} / \mathrm{L})$, and NPBD was bactericidal to P. vulgaris but not to P. mirabilis. This is perhaps not surprising considering the confusing taxonomy of the Proteus, Providencia, Morganella group and their biochemical differences [19]. The Enterobacteriaceae and Pseudomonadaceae with LPS rich envelopes were the least susceptible group with MIC $\geq 512 \mathrm{mg} / \mathrm{L}$. Six species which tolerated 5\% DMSO well had average MBC $\leq 4 \times$ MIC, indicating a bactericidal effect (Table 1). These saprophytic species are adapted to complex environments and encode multiple membrane transporter proteins which export a wide range of xenobiotics, while intracellular and commensal species have limited and more specialized systems [20]. Efficient export may explain the low efficacy of NPBD against the Enterobacteriaceae and Pseudomonadaceae. The higher activity against LOS-type enteric 
species is unlikely to be due to penetrability. NPBD was equally effective against a C. jejuni LOS deficient mutant and the parent strain. NPBD does not alter membrane permeability of E. coli or damage spheroplasts of E. coli and M. catarrhalis [12]. NPBD MIC/MBC for antibiotic-resistant clinical isolates of S. aureus, E. faecalis, E. faecium, P. mirabilis, E. coli and $C$. jejuni were similar to those of laboratory strains suggesting no cross resistance to the classes of antibiotics tested (Table 1). S. aureus strains were resistant to three or more antibiotics, including nine resistant to methicillin, and all 4-fold to 16-fold more resistant to ciprofloxacin than ATCC 29213 (Tables S7-S9). Ciprofloxacin showed high and uniform activity across all species and MIC ranges tor type strains were within CLSI and EUCAST ranges. The activity pattern indicates broadly distributed and highly susceptible target(s) (Table S6).

In summary, NPBD showed high to moderate activity against Gram-positive and more variable and selective activity against Gram-negative species. It is active against Staphylococcus and Enterococcus species which cause problematic antibiotic-resistant infections. It is bactericidal to enteric pathogens $C$. difficile, C. perfringens, Y. enterocolitica and Campylobacter spp., to urogenital pathogens $N$. gonorrhoeae. and to respiratory tract pathogens $H$. influenzae, S. pneumoniae, S. pyogenes, M. catarrhalis, N. meningitidis and Acinetobacter species. It inhibits urogenital pathogens Chlamydia trachomatis [12] and Candida albicans [15] and respiratory pathogen $M$. tuberculosis (Table S10). For skin and mucosal infections where higher concentrations are achievable it could be an effective antimicrobial agent. NPBD also inhibits virulence factors in vitro; prodigiosin production in Serratia marcescens, cell adherence and invasion by Y. enterocolytica and motility in Proteus spp. [12]. Inhibition of virulence factors would contribute to infection control at skin and mucosal surfaces.

Many species naturally produce phenotypically variant sub-populations which survive in response to stresses and which, on culture, manifest as slow growing small colony variants (SCV). Variants show diverse transient or stable metabolic changes, such as auxotrophies and defective electron transport, and, under non-stress conditions, can revert to the parental or to different distinct phenotypes [21]. NPBD at concentrations above the MIC induced the emergence of tolerant sub-populations in S. aureus, manifesting as SCV that were phenotypically unstable and not intrinsically resistant to NPBD, their prevalence depending on the presence NPBD (Figure S3).

The growth inhibitory activity of NPBD reported here indicates that it is targeting PTP involved in primary metabolism which, alone or in combination, are necessary to viability, cell cycle progression or cell division. Tyrosine phosphatases play significant roles in bacterial responses to environmental stresses and in activities which enable infection and protect against host defences [8]. Tyrosine signaling also interacts with bacterial second messenger, cyclic di-guanosine monophosphate, and quorum-sensing auto-inducers in virulence activities $[8,22]$. NPBD inhibits many virulence factors in bacteria which involve PTP signaling. Although important to the activity profile of a PTP inhibitor, these are not of immediate relevance to explaining the effects of NPBD presented in this paper [12] and Nicoletti unpublished.

Few bacterial PTPs have been characterized and most are linked to species-specific functions, many of relevance to infectivity. They provide examples of likely targets for inhibition by a PTP inhibitor. S. aureus has the non-essential LMWPTPs, PtpB and PtpA, the latter being important to survival and infectivity [23]. B subtilis LMWPTP, YwlE, and Yfkj are involved in stress resistance [24]. A BY-K, PtkA with no identified cognate PTP is involved in DNA replication in B. subtilis [25]. Two putative PTKs and one PTP similar to proteins in B. subtilis and S. pneumoniae are reported in E. faecium [26]. S. pyogenes encodes no BY-K but has a DSP, SP-PTP, which positively regulates growth, cell division and expression of virulence genes. LMWPTP Spd1837 in S pneumoniae is involved in virulence but not capsule production [27]. Y. enterocolitica YopH is essential to virulence [8]. NPBD inhibits YopH enzymatic activity and adhesion and invasion of human cells [12].

Of more significance to growth inhibition are PTP reported to be involved in many aspects of primary metabolism. Complex cross-phosphorylation between STKs, BY-Ks and 
phosphatases are involved in DNA metabolism, transcription, cell division and sporulation in B. subtilis [28]. Phosphorylation on Ser, Thr and Tyr regulate binding proteins that modulate DNA repair and replication in B. subtilis and E. coli [29]. PTPs regulate binding of transcription factors to DNA in B. subtilis, S. pneumoniae, S. aureus and K. pneumoniae [30]. Tyrosine phosphorylation negatively regulates the $\beta$-subunit of RNA polymerase (RpoB), which modulates transcription in S. pneumoniae, Helicobacter pylori and K. pneumoniae [31]. In B. subtilis PtkA, PtkB and PtpZ regulate RpoB [28]. Tyrosine replacement in the RpoB binding site in $E$. coli decreases RpoB affinity for DNA, suppressing capsular polysaccharide production [32]. The ultimate effect of inhibition of PTPs negatively regulating rpoB will depend on the functions of expressed proteins. NPBD suppresses endospore formation in B. subtilis and down-regulates RNA binding protein SpoVG which is associated with cell division and initiation of sporulation [12,33]. Deletion of SpoVG in S. aureus reduces methicillin and vancomycin resistance [34]. NPBD was active against VRE and MRSA strains (Table 1) and may inhibit a PTP positively regulating SpoVG expression. Mycobacterium tuberculosis PtpA positively regulates human and mycobacterial ATP synthase $\alpha$-subunit AtpA, resulting in down-regulation of AtpA, reduced ATP synthesis and reduced growth. Orthovanadate inhibits PtpA resulting in down-regulation of AtpA, reduced ATP synthesis and reduced growth [35]. Mtb is sensitive to high ROS levels and has difficulty maintaining redox homeostasis [36]. NPBD inhibits the growth of Mtb in vitro ([37], Table S10). The above examples illustrate the complexity of tyrosine signaling in bacteria and the positive and negative effects of inhibition of particular PTPs. The physiological result of exposure to an inhibitor indicates the balance of inhibition or promotions of all susceptible PTP. The functional diversity of PTPs from those in higher organisms suggests that inhibition can be selective. As more PTPs are isolated and characterized a more co-ordinated understanding of the complex role of tyrosine signaling in bacteria will emerge. The value of selective PTP inhibitors is to identify new physiological functions which involve PTP.

\subsection{Plasma Binds NPBD, Lowering the Bioavailability of NPBD}

Protein binding by covalent, electrostatic or hydrogen bonding affects the pharmacokinetics and pharmacodynamics of a drug, reducing the level of free drug in blood and tissues and affecting the efficacy of antibiotics [38]. NPBD binds strongly and reversibly $(84 \% \pm 4.2)$ to human serum albumin (HSA), the predominant redox thiol in plasma (Table S11). The effect on antibacterial activity of binding of NPBD to blood proteins was estimated by determination of MIC/MBC titres in the presence of plasma. Antibacterial activity was reduced in a dose dependent manner in the presence of increasing plasma levels. A 50\% plasma concentration increased 32-fold the MIC for S. aureus and S. pyogenes and the MBC for S. pyogenes (Table S12). This data suggests the dosing required for inhibition of staphylococci and streptococci in blood and tissues would be considerably higher than dosing based on the standard MIC titre. There are no established quantitative relationships between blood protein binding in vitro and in vivo but inhibition of antibacterial activity is a predictor of lowered bioavailability in blood and tissues [38]. HSA is the predominant redox thiol in plasma and its reduction of NPBD would lower bioavailability.

\subsection{Thiol Reduction of NPBD Decreases Antimicrobial Activity}

Low molecular weight thiols are nucleophiles and reductants acting as redox buffers to maintain a reduced cytosol and preserve thiol enzyme cofactors, Cys-dependent antioxidant enzymes and PTPs [7]. LMWT, present in highly reduced form in mM concentrations, vary in type and level across bacteria, fungi and unicellular protozoa to meet diverse oxidative conditions. The major ROS scavengers in bacteria are glutathione (GSH) or the cysteinyl glycosides (bacillithiols or mycothiols), free cysteine, and Co-enzyme A [7,39].

The interaction of thiols with NPBD was investigated by the effect of cysteine and dithiothreitol on the MIC/MBC for S. aureus, E. faecalis, B. subtilis and P. vulgaris. Molar excess ( 1 and $10 \mathrm{mM}$ ) of cysteine and dithiothreitol increased the MIC for all species in a dose-dependent manner, $10 \mathrm{mM}$ increased the $\mathrm{MIC} \leq 2$-fold for cysteine and 20 -fold 
for DTT (Table 2). The differing effects of thiol excess in the test species may reflect the species-specific nature of LMWT. Most Gram-positive bacteria, including Staphylococcus and Bacillus, use cysteine and bacillithiols. Gram-negative bacteria and some Gram-positive species, including Enterococcus and Streptococcus, use cysteine and GSH or mycothiols [39]. Actinobacteria, including Corynebacterium and Mycobacterium, use mycothiols. Reductive inactivation of NPBD in the presence of thiols confirmed that oxidation of thiols contributed selectively to disruption of bacterial cell redox balance thus contributing to oxidative stress and indirect repression of PTP function.

Table 2. Antibacterial activity ${ }^{\text {a }}(\mathrm{mg} / \mathrm{L})$ of NPBD in the presence of 1 and 10 molar excess of cysteine and dithiothreitol.

\begin{tabular}{cccccc}
\hline & \multirow{2}{*}{ CAMHB Control } & \multicolumn{2}{c}{ Cysteine (mM) } & \multicolumn{2}{c}{ Dithiothreitol (DTT) (mM) } \\
\cline { 3 - 6 } & & $\mathbf{1}$ & $\mathbf{1 0}$ & $\mathbf{1}$ & $\mathbf{1 0}$ \\
\hline S. aureus ATCC 29213 & 4 & 4 & 6 & 32 & 304 \\
E. faecalis ATCC 29212 & 10 & 10 & 23 & 21 & 362 \\
B. subtilis ATCC 6633 & 5 & 7 & 11 & 362 & 215 \\
P. vulgaris ATCC 13315 & 6 & 8 & $11.1 \pm 7.3$ & $15.6 \pm 11$ & $304 \pm 69$ \\
\hline Mean \pm SEM & $5.9 \pm 2.6$ & $6.8 \pm 2.5$ & 11 & 32 \\
\hline
\end{tabular}

${ }^{a}$ MIC determined by broth microdilution (CLSI, M07-A8) with and without addition of excess cysteine or DTT. No effect on MIC for $0.1 \mathrm{mM}$. The MIC of ciprofloxacin for S. aureus was within QC range $(0.25 \mathrm{mg} / \mathrm{L})$.

\subsection{NPBD Shows Varying Bactericidal Action on Rapidly Growing, Slowly Growing and Non-Growing Bacteria}

Investigation of the dynamic effect of NPBD under different growth conditions was assessed by time-kill (TK) assays. The relationship between agent concentration and its effect on population density over time is expressed as kill curves or as $\log _{10}$ reduction factors (RF) [40]. Patterns of bactericidal rates under different growth conditions can reveal agent effects on dormant and slow-growing cells and the presence of phenotypically variant sub-populations of agent-refractory cells, which may contribute to treatment failure and chronic infection [41].

The bactericidal activity of NPBD (2-8× MIC) was assessed for Gram-positive and Gram-negative species by TK assays in broth and in distilled water at room temperature where cells would be non-replicating. Population reduction patterns differed between species and for replicating and non-replicating cells, reflecting the variation in functions of targeted PTPs (Figures 2 and 3).

NPBD showed rapid dose-dependent reduction of C. xerosis and B. subtilis in broth and of B. subtilis in water (Figure 2). The kill rates for LOS-type M. catarrhalis and $Y$. enterocolitica in broth and A. calcoaceticus in water were rapid and dose-dependent (Figure 3). NPBD reduced $P$. vulgaris cells rapidly in broth, with low-level dose-dependence, but did not kill cells in water. Dose-dependent suppression in broth and water suggests the inhibition of PTP(s) necessary for cell viability. Dose dependent reduction in broth but not water suggests affected PTP(s) are involved in replication but are not essential. NPBD showed slow, dose-independent population reduction of $S$. aureus and E. faecalis in broth and water (Figure 2$)$. NPBD $(2 \times$ MICi) was equally inhibitory to rapidly (RF 0.8$)$ and slowly growing (RF 0.9) S. aureus, however, less reduction of non-metabolizing cells (RF $0.3)$, suggests NPBD affects replication and is truly bacteriostatic to staphylococci and enterococci (Figure 4). Exponentially replicating cells of S. aureus are rapidly killed by 'bactericidal' aminoglycosides, daptomycin, beta-lactams, quinolones and vancomycin (10-50 $\times$ MIC), but only aminoglycosides and daptomycin are bactericidal to stationary phase populations [42]. 
(a)

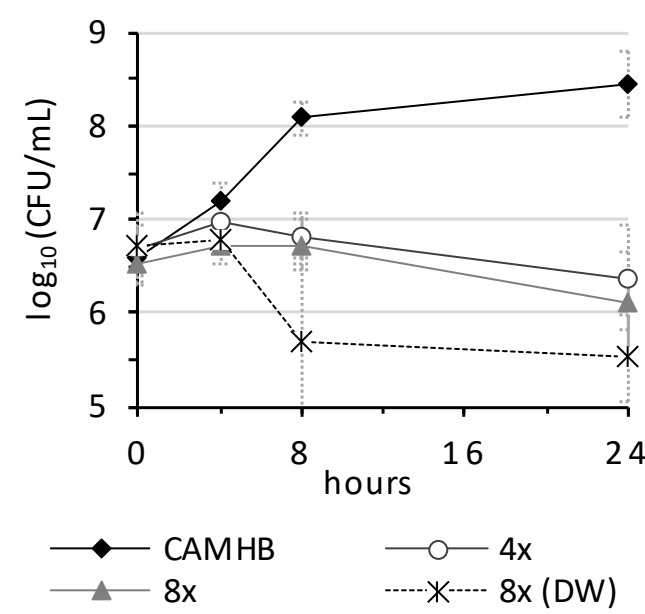

(c)

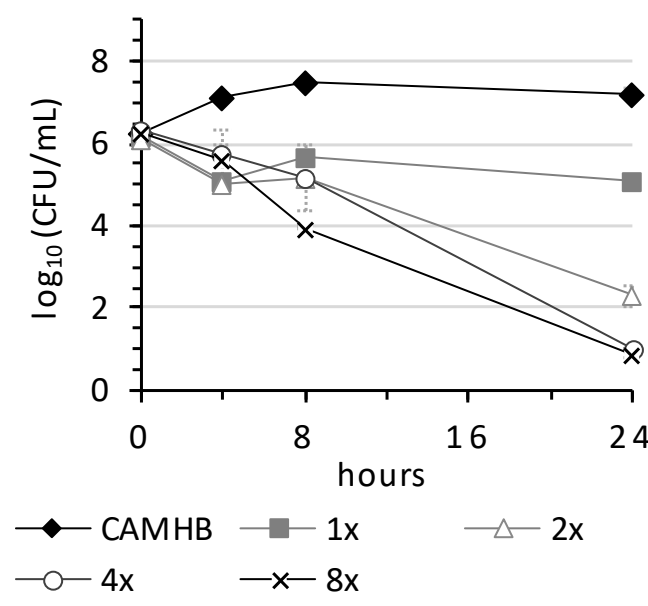

(b)

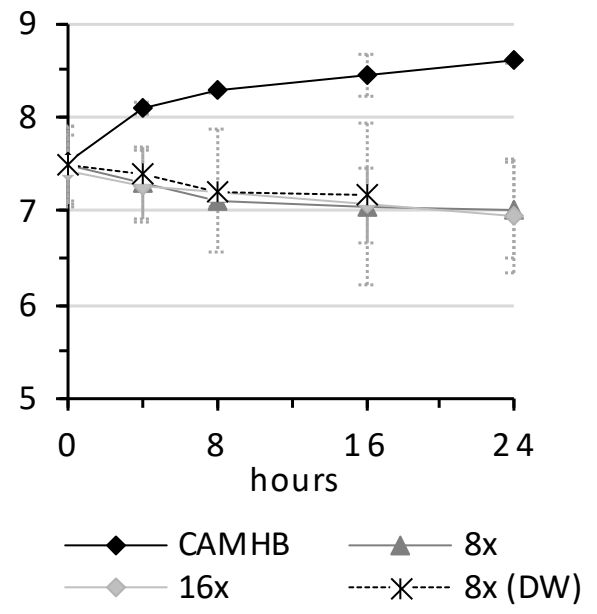

(d)

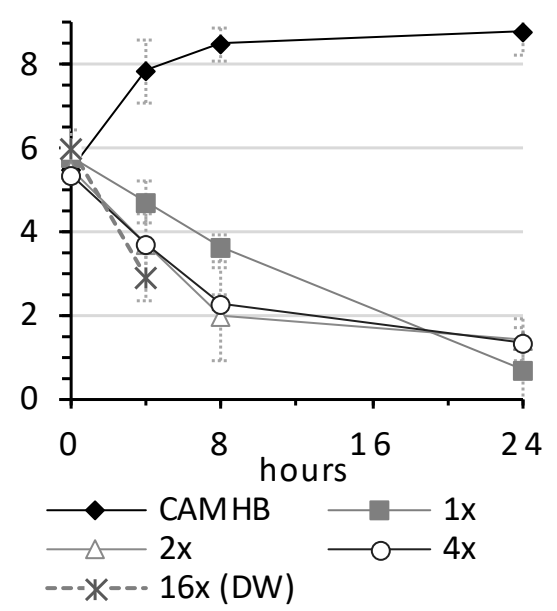

Figure 2. Bactericidal rates of NPBD for Gram-positive species. (a) Staphylococcus aureus ATCC29213, (b) Corynebacterium xerosis RMIT53/5, (c) Enterococcus faecalis ATCC29212, (d) Bacillus subtilis ATCC6633 in CAMHB or distilled water (DW). NPBD was tested at multiples of the MICi in CAMHB with $1 \% v / v$ DMSO. Limit of detection $<10 \mathrm{cfu}$. Assays repeated 2-4 times and average viable counts reported. 
(a)

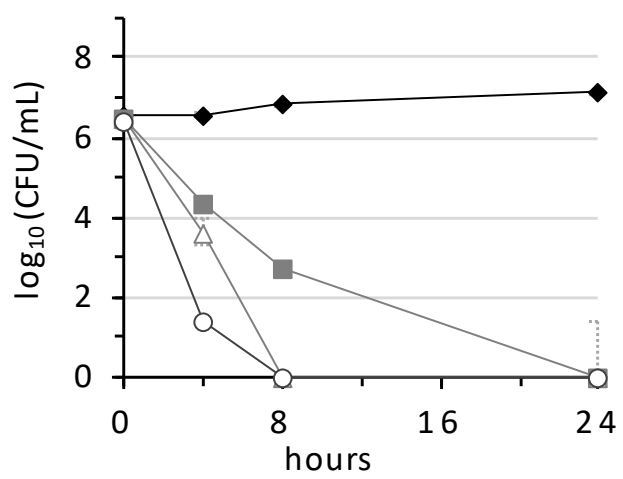

$\neg \mathrm{CAMHB} \longrightarrow 1 \mathrm{x} \longrightarrow \triangle \mathrm{2x} \rightarrow-4 \mathrm{x}$

(c)
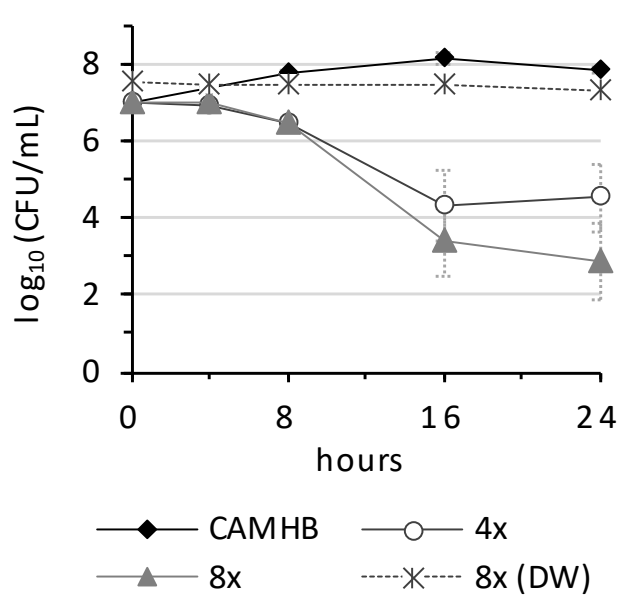

(b)

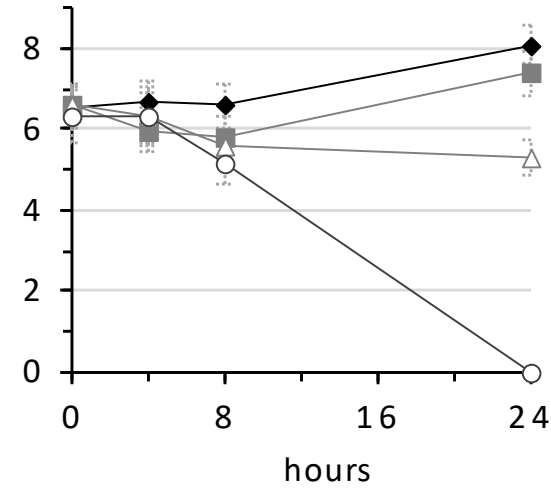

$\neg \mathrm{CAMHB} \longrightarrow 1 \mathrm{x} \longrightarrow \triangle 2 \mathrm{x}-\mathrm{O}-4 \mathrm{x}$

(d)

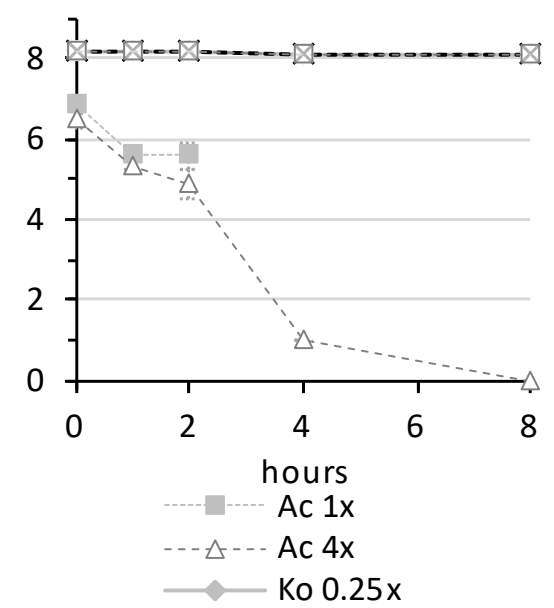

Figure 3. Bactericidal rates for NPBD against Gram-negative species. (a) Moraxella catarrhalis RMIT211/2, (b) Yersinia enterocolitica ATCC23715, (c) Proteus vulgaris ATCC13315 in CAMHB or distilled water (DW); and (d) Acinetobacter calcoaceticus RMIT3131 and Klebsiella oxytoca RMIT 180/4 in distilled water. NPBD was tested at multiples $(\times)$ of the MICi in CAMHB with $1 \% v / v$ DMSO. Limit of detection was $<10 \mathrm{cfu}$. Assays repeated two to four times and average viable counts reported. 
(a)
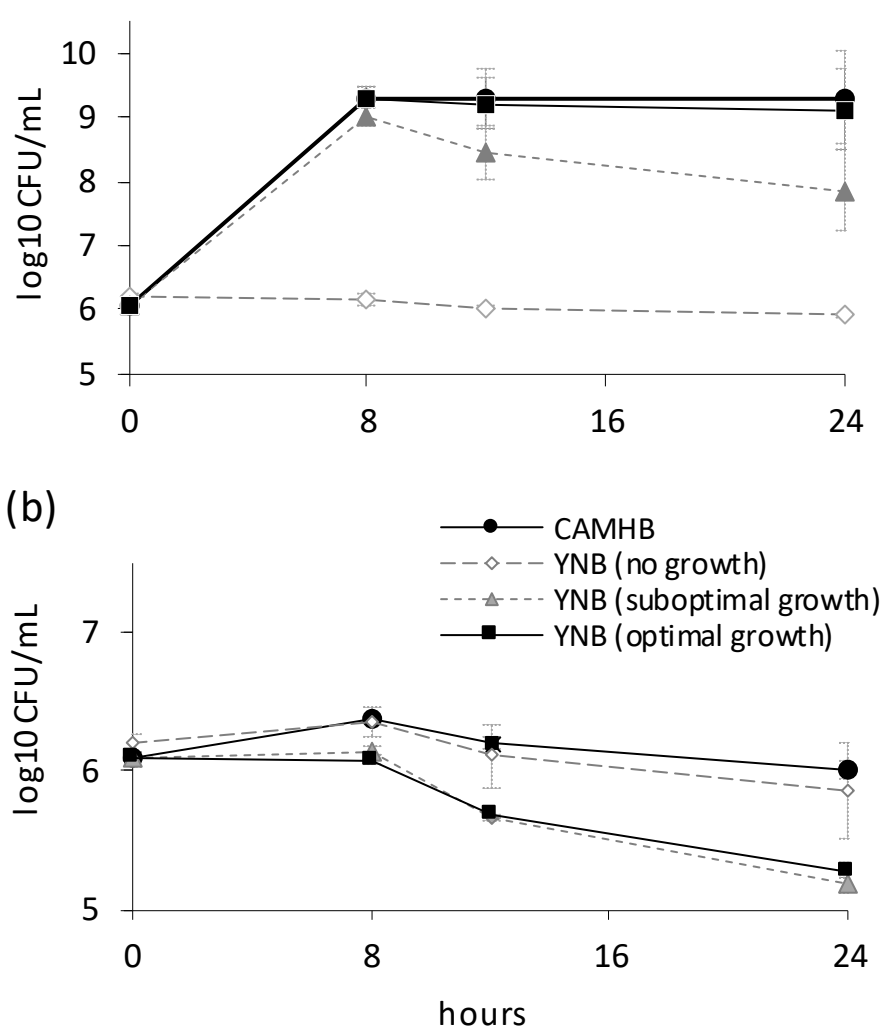

Figure 4. NPBD kills slow-growing cells of $S$. aureus at the same rate as rapidly growing cells. Rate of growth of S. aureus ATCC ATCC29213 in CAMHB and in media supporting no growth, suboptimal growth and optimal growth with (a) no NPBD and (b) $16 \mathrm{mg} / \mathrm{L}$ NPBD ( $\times$ MICi). Yeast Nitrogen Broth formulations: YNB without additives (no growth); YNB with $0.01 \% w / v$ glucose and $0.0017 \%$ $w / v$ Casamino acids (suboptimal growth); YNB with $0.5 \% w / v$ glucose and $1.7 \% w / v$ Casamino acids (optimal growth). Final formulation contained 1\% DMSO.

\subsection{NPBD Has Low Level Interactions with Bacteriostatic and Bactericidal Antibiotics}

A comparison can be made, using a static MIC chequerboard titration, of the growth inhibitory effect of two agents in combination compared to either agent alone. When using drug concentrations achievable in vivo, this method provides efficacy data to guide combination therapy [43]. The chequerboard assay was here used to investigate interactions between NPBD and four antibiotics differing in mechanism and degree of activity against S. aureus and E. faecalis. Tetracycline and erythromycin interfere with different aspects of ribosomal function and are designated as 'bacteristatic' drugs for pharmacokinetic purposes. Vancomycin and ciprofloxacin are 'bactericidal'. Vancomycin interferes with cell wall synthesis and alters membrane permeability. Ciprofloxacin interferes with DNA gyrase and topoisomerase, inhibiting separation of DNA strands and thus inhibiting cell division [44].

The concentration of each agent in inhibitory combinations, relative to the inhibitory concentration of each agent alone, is used to derive a fractional inhibitory concentration index (FICI), categorized by defined value ranges of pharmacodynamic usefulness: FICI $<0.5$ indicating synergy, $>0.5$ to $<4$ no significant interaction, and FICI of $>4$ indicates antagonism [43]. The FICI for S. aureus and E. faecalis for NPBD/antibiotic combinations indicated no interaction (Table 3). 
Table 3. Antibacterial efficacy of NPBD/antibiotic combinations for S. aureus and E. faecalis.

\begin{tabular}{|c|c|c|c|c|c|}
\hline & & \multicolumn{4}{|c|}{ FICI $^{a}$ and Median $\Sigma F^{\prime}{ }^{b}$ (Range) for NPBD in Combination with Antibiotics: } \\
\hline & & Erythromycin & Ciprofloxacin & Vancomycin & Tetracycline \\
\hline \multirow[t]{3}{*}{ S. aureus } & FICI & $1.4 \pm 0.4$ & $0.99 \pm 0.25$ & $1.15 \pm 0.3$ & $0.92 \pm 0.25$ \\
\hline & $\Sigma \mathrm{FIC}_{\min }$ & $0.88(0.75-1.02)^{\mathrm{c}}$ & $1(0.27-1.03)$ & $1(0.56-1.01)$ & $0.76(0.52-1)^{\mathrm{c}}$ \\
\hline & $\Sigma F I C_{\max }$ & $1.38(1.25-1.5)^{\mathrm{c}}$ & $1.25(1.01-4.5)$ & $1.5(1.25-4)$ & $1.38(1.25-1.5)^{\mathrm{c}}$ \\
\hline \multirow[t]{3}{*}{ E. faecalis } & FICI & $0.75 \pm 0.22$ & $1.09 \pm 0.16$ & $1.03 \pm 0.29$ & $0.51 \pm 0.12$ \\
\hline & $\Sigma \mathrm{FIC}_{\min }$ & ND & $0.75(0.56-1)$ & $0.5(0.38-1.03)$ & $0.19 *(0.19-0.25)$ \\
\hline & $\Sigma \mathrm{FIC}_{\max }$ & ND & 1.13 (1.13-2.13) & $1.13 *(1.02-1.5)$ & $1.03 *(0.56-1.06)$ \\
\hline
\end{tabular}

a Fractional Inhibitory Concentration Index: FICI $<0.5$ indicates synergy, $>0.5$ to $<4$ indicates no interaction, and $>4$ indicates antagonism;

${ }^{\mathrm{b}} \Sigma \mathrm{FIC}_{\max } \geq 2$ is proposed as indicative of antagonism, and $\Sigma \mathrm{FICmin}<0.75$ of synergy; ${ }^{\mathrm{c}} \mathrm{N}=2 ;{ }^{*}$ statistical significance for $E$. faecalis synergism NPBD/Tetracycline 0.00074, and antagonism NPBD/Vancomycin 0.017, NPBD/Tetracycline $0.01(p=0.05)$.

The inhibitory potency of NPBD/antibiotic pairs was further characterized by summation of all FIC showing minimum $\left(\Sigma \mathrm{FIC} \mathrm{min}_{\min }\right)$ and maximum inhibition $\left(\sum \mathrm{FIC} \max \right)$ where a $\Sigma \mathrm{FIC}_{\max } \geq 2$ is considered indicative of antagonism and $\Sigma \mathrm{FIC}_{\min }<0.75$ of synergy [45]. NPBD did not modify the activity of ciprofloxacin, vancomycin or erythromycin for $S$. aureus, indicated by the small difference between $\Sigma F I C_{\min }$ and $\Sigma \mathrm{FIC}_{\max }$. The result for tetracycline was close to the cut-off for synergism $\left(\Sigma F I C_{\min } 0.76\right)$. For E. faecalis, NPBD enhanced the activity of tetracycline $\left(\Sigma F I C_{\min } 0.19\right)$ and ciprofloxacin $\left(\Sigma F I C_{\min } 0.5\right)$ and was equal to the cut-off for synergism for vancomycin $\left(\Sigma\right.$ FIC $\left.C_{\min } 0.75\right)$ (Table 3). FIC indices assume that test drugs have similar linear dose-response curves whereas antibiotics generally show varying kill patterns [46].

The effect of NPBD on the bactericidal rate of tetracycline for E. faecalis was investigated by TK assays. NPBD $(1 \times-16 \times \mathrm{MICi})$, showed a dose-independent, slow bactericidal effect compared to the dose-dependent kill rate of tetracycline (Figure 5a,b). Equal concentrations of NPBD and tetracycline $(1 \times-16 \times$ MICi) had a lower dose-dependent reduction than tetracycline alone (Figure $5 \mathrm{c}$ ).

Bacteriostatic drugs generally have antagonistic effect on the kill rates of bactericidal drugs and such effects are greater where different metabolic functions are targeted and where differences in growth rates are significant, suggesting the effect on growth dynamics is more significant than the difference in mechanism of action [46]. The lesser bactericidal activity of NPBD may explain its antagonistic effect on the kill rate of tetracycline. Tetracycline has a broad antimicrobial spectrum, inhibits RNA viruses and Plasmodium falciparum, and has many metabolic functions in human cells, but no involvement with tyrosine signaling is reported [47]. Many bactericidal antibiotics induce oxidative damage including ciprofloxacin, for which a marginal interaction was noted, and tetracycline [48]. A thiol oxidant potentiates the activity of isoniazid in M. tuberculosis [49]. NPBD may enhance efficacy by contributing to oxidative damage which could differ between antibiotics and the spectrum of redox thiols in species. E. faecalis contains the tripeptide GSH and S. aureus, a cysteinyl-glycoside (bacillithiol). NPBD oxidation of cysteine increased the MIC twofold for E. faecalis but not for S. aureus, suggesting a stronger redox reaction with GSH (Table 2). 


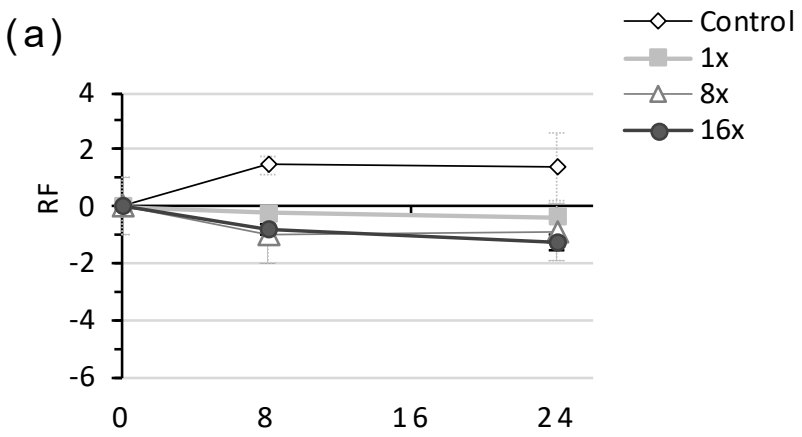

(b)

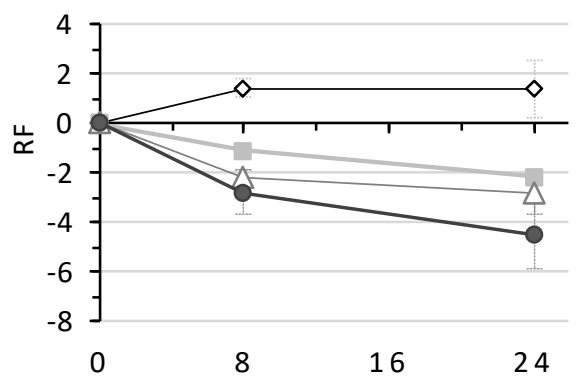

(c)

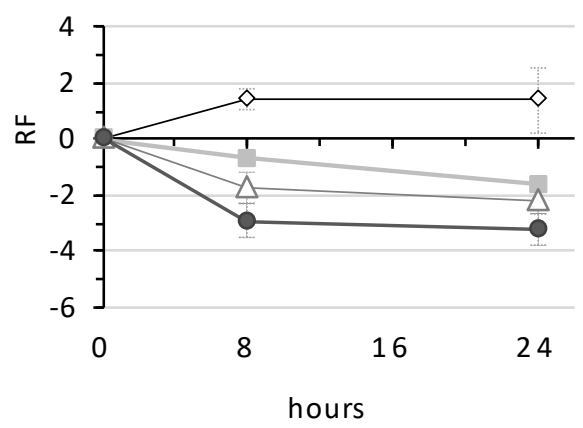

Figure 5. Antagonistic effect of NPBD on the action of tetracycline against Enterococcus faecalis. (a) NPBD alone; (b) Tetracycline (c) NPBD \& tetracycline in equal proportions. MICi for tetracycline and NPBD was $16 \mathrm{mg} / \mathrm{L}$.

\subsection{NPBD Does Not Induce or Select for Resistant Variants in Antibiotic-Resistant Species}

The ability of an agent to induce drug-resistant mutants or select for drug tolerance is relevant to the potential for development of clinical resistance. Drug tolerant cells are a common feature of bacterial populations in vivo, contributing to recurrent and chronic infections [21]. Antibiotic resistance arises through accumulation of mutations, both targetspecific and related to general metabolic functions, which may alter susceptibility to other antibiotics [48]. Vancomycin-resistant E. faecium and S. aureus (VISA) show unstable mutations, altered metabolic functions and altered susceptibility to antibiotics [50]. Mutation in rpoB contributes to vancomycin resistance in MRSA, VISA and E. faecium. Rifampinresistant MRSA with rpoB mutations show lower susceptibility to vancomycin [51].

Development of resistance in a strain is indicated by an irreversible increase in MIC that is greater than the accepted MIC titre range and is assessed in vitro by long-term exposure to sub-inhibitory drug concentrations. Genetic stability of mutants is tested by reassessment of the MIC after drug-free subculture. Drug-tolerant cells exhibit a sustained higher MIC which, on drug removal, reverts to the original strain susceptibility.

The development of resistance to NPBD by MRSA and VRE strains was assessed after exposure for 16 weeks with weekly monitoring of strain MIC. No strain developed stable 
resistant populations (Figure 6). Weekly MIC titres varied $\leq 4$-fold and MBC titres were $\leq 2 \times$ MIC. MIC and MBC titres after drug-free passages differed $\leq 4$-fold. There was no sustained rise in the MIC of any strain to suggest the presence of NPBD-tolerant cells. The low probability of multiple PTP mutations to resistance suggests emergence of resistance to NPBD would be delayed. Many antibiotics provoke resistance mutations in bacterial anti-oxidative enzymes [48]. NPBD has the advantage of dual mechanisms as an oxidant and PTP inhibitor in delaying the emergence of resistant strains.

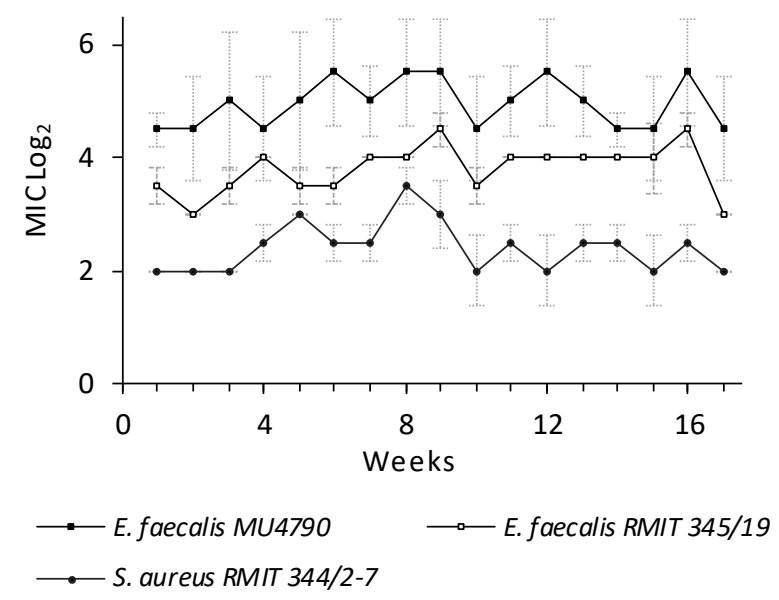

Figure 6. Weekly $\left(\mathrm{W}_{1}-\mathrm{W}_{16}\right)$ geomean MIC of VRE and MRSA. Strains, serially cultured for 16 weeks in CAMHB with NPBD, subculture to fresh dilution sets, $W_{1}$ to $W_{15}$, and serial passage in CAMHB to $W_{16-17}$. MIC $/ M B C W_{0}$ and $W_{17}$ were determined by broth microdilution $([28,29]$, Table S8, Table S9). Inoculum density $W_{1}$ to $W_{15}$ varied $<1 \log _{10}$. Assays were repeated twice. MBC $\leq 2 \times$ MIC. $2.5 \%$ DMSO. Weekly inocula of $1-5 \times 10^{5} \mathrm{cfu} / \mathrm{mL}$ standardized and verified by viable count.

The complementary mechanisms of action of NPBD, selectively suppressing tyrosine phosphatases and disrupting redox balance in microbial cells, could make it an effective rapid broad-spectrum agent for clinically significant drug-resistant variants with limited therapeutic options [52]. Its activity profile suggests NPBD could be an effective drug for the treatment of skin and mucosal infections and tissue-localized infections where direct drug delivery is possible and higher concentrations achievable. The broad activity patterns of NPBD illustrate the diversity of function and distribution of PTPs in bacteria and is a significant contribution supporting the proposal that PTPs and redox thiols are selective targets for antibacterial drugs. Difficulties in the identification of selective, bioavailable, small molecule PTP inhibitors of validated human disease targets has delayed drug development [53]. A variety of similar inhibitor molecules are being investigated to treat human diseases such cancer, diabetes and obesity $[54,55]$. This report contributes to the attractiveness of development of antimicrobial PTP inhibitors. Given the greater functional diversity of microbial tyrosine phosphatases, such candidates are likely to be more successful than PTP inhibitors directed to cancer and other human diseases. Interference with redox balance is also gaining traction for direct inhibition or potentiation of existing antimicrobial drugs [56-58].

\section{Materials and Methods}

\subsection{Chemicals, Reagents, Bacterial Strains}

GMP NPBD 0.2M stock solutions in DMSO (AnalaR ${ }^{\circledR}$, BDH Chemicals, Leicestershire, England); Ciprofloxacin (MP Biomedicals); Media, supplements, Anaerogen ${ }^{\mathrm{TM}}$, Campygen $^{\mathrm{TM}}$ (Oxoid, Cambridge, UK). Yeast Nitrogen broth, Brucella broth (BBL ${ }^{\mathrm{TM}}$ ). Test strains obtained from ATCC, NCTC, RMIT Culture Collection. Clinical isolates from human pathology laboratories (Tables S6-S8). A summary of the physicochemical properties of NPBD is provided in Table S1. 


\subsection{MIC and MBC Broth Microdilution Assays}

MIC/MBC were determined by CLSI broth microdilution [59,60]. All test systems contained $1 \% v / v$ DMSO. Reported MIC is lowest concentration showing no visible growth (100\% inoculum inhibition). MIC and MBC are reported as geometric mean titres from all replicates. The effect of inoculum density on MIC was determined for assays and reported as MICi (Table S13).

\subsection{Time-Kill Assays}

The MICi in CAMHB was determined for 8 representative bacterial strains. NPBD at multiples of the MICi was prepared in CAMHB prewarmed to $37^{\circ} \mathrm{C}$, or DW at RT, inoculated with $\log$ phase cultures to give final $\sim 5 \times 10^{6} \mathrm{cfu} / \mathrm{mL}$, incubated, shaking, at $37^{\circ} \mathrm{C}$ or RT and sampled at intervals to $24 \mathrm{~h}$. Cell density was measured by viable count and expressed as time-kill curves and $\log _{10}$ RF. Assays were repeated two to four times and average counts reported.

\subsection{Effect of NPBD on Population Growth under Optimal and Growth Limiting Conditions}

Population growth was assessed in CAMHB (control) and YNB broth: YNB without additives (no growth); YNB with $0.01 \% w / v$ glucose and $0.0017 \% w / v$ Casamino acids (suboptimal growth); YNB with $0.5 \% w / v$ glucose and $1.7 \% w / v$ Casamino acids (optimal growth). NPBD test concentrations $(0.5 \times, 1 \times, 2 \times \mathrm{MICi})$ were inoculated with final logphase $1 \times 10^{6} \mathrm{cfu} / \mathrm{mL}$ suspension, incubated at $37^{\circ} \mathrm{C}$ and cell density measured as above.

\subsection{NPBD Interaction with Antibiotics}

NPBD (0.06-64× MIC), erythromycin, tetracycline, ciprofloxacin and vancomycin $(0.01-16 \times \mathrm{MIC}) \log _{2}$ dilutions in CAMHB were dispensed to microtitre plates with increasing concentrations of each drug on adjacent axes and inoculated with log-phase $\left(1 \times 10^{6} \mathrm{cfu} / \mathrm{mL}\right)$ test suspensions. Concentrations for each agent alone and in combinations for wells showing no visual growth were recorded as Fractional Inhibitory Concentrations (FIC). A FIC index (FICI) representing the sum of FICs of antibiotic (A) with NPBD (B) was calculated as:

$$
\Sigma \mathrm{FIC}=\mathrm{FIC}_{\mathrm{A}}+\mathrm{FIC}_{\mathrm{B}}=\left(\frac{\mathrm{C}_{\mathrm{A}}}{\mathrm{MIC}_{\mathrm{A}}}\right)+\left(\frac{\mathrm{C}_{\mathrm{B}}}{\mathrm{MIC}_{\mathrm{B}}}\right)
$$

where $\mathrm{MIC}_{\mathrm{A}}$ and $\mathrm{MIC}_{\mathrm{B}}$ are the $\mathrm{MIC}$ of each agent alone and $\mathrm{C}_{\mathrm{A}}$ and $\mathrm{C}_{\mathrm{B}}$ are the concentrations of each agent in effective combinations. FICI $<0.5$ indicates synergy, FICI $>0.5$ to $<4$ no interaction, and FICI $>4$ antagonism [43]. The highest $(\Sigma \mathrm{FIC} \max )$ and lowest $\left(\Sigma \mathrm{FIC} \mathrm{Cin}_{\min }\right)$ were reported to provide higher sensitivity in detecting interactions, $\Sigma \mathrm{FIC}_{\max } \geq 2$ indicating antagonism and $\Sigma \mathrm{FIC}_{\min }<0.75$ indicating synergism [45]. A time kill assay was performed as above for E. faecalis exposed to equal concentrations $(8-256 \mathrm{mg} / \mathrm{L}$ in CAMHB $+1 \% \mathrm{DMSO}$ ) of NPBD and tetracycline sampled at $0,4,8$ and $24 \mathrm{~h}$.

\subsection{Development of Resistance on Continuous Exposure to NPBD}

Vancomycin resistant E. faecalis and MRSA S. aureus were exposed to NPBD for 16 weeks. Each strain $\left(1-5 \times 10^{5} \mathrm{cfu} / \mathrm{mL}\right.$ final) was inoculated $\left(\mathrm{W}_{0}\right)$ into a $1 \mathrm{~mL} \log _{2}$ dilution set 1 of NPBD (256-0.5 mg/L in CAMHB), incubated at $37^{\circ} \mathrm{C}$ aerobically and sub-cultured weekly to fresh dilution sets and weekly MIC $\left(\mathrm{W}_{1}\right.$ to $\left.\mathrm{W}_{16}\right)$ recorded. Representative colonies from $\mathrm{MBC}_{\mathrm{W} 16}$ plates were sub-cultured $3 \times$ in drug-free medium. The $\mathrm{W}_{0}, \mathrm{~W}_{16}$ and $\mathrm{W}_{17} \mathrm{MIC} / \mathrm{MBC}$ were measured by microbroth dilution [60]. Acquisition of resistance was accepted as a $>4$-fold increase in the $\mathrm{MIC}_{\mathrm{W} 17}$ compared to $\mathrm{MIC}_{\mathrm{W} 0}$.

\section{Patents}

- Denisenko, P.P.; Sapronov, N.S.; Tarasenko, A.A. Antimicrobial and radioprotective compounds. US Pat 9,045,452, 2 June 2015. [Claim: A method for the treatment of a gastrointestinal infection] 
- Denisenko, P.P.; Sapronov, N.S.; Tarasenko, A.A. Antimicrobial and radioprotective compounds. US Pat 8,569,363, 29 October 2013. [Claim: A method for the therapeutic treatment of a skin or soft tissue infection]

- Denisenko, P.P.; Sapronov, N.S.; Tarasenko, A.A. Antimicrobial and radioprotective compounds. US Pat 7,825,145, 2 November 2010. [Claim: A method of treating vulvo-vaginitis]

- Nicoletti, A.; White, K. Protein tyrosine phosphatase modulators. WO/2008/061308, 29 May 2008.

Supplementary Materials: The following are available online at https:/ /www.mdpi.com/article/10 .3390 /antibiotics10111310/s1, Figure S1: Molecular structures of nitroalkene benzenes and interacting molecules, Figure S2: Mean Compound (1) plasma concentrations versus time following a single dose of $1000 \mathrm{mg} / \mathrm{kg}$, Figure S3. Miniature (left) and normal (right) colonies of S. aureus exposed to $32 \mu \mathrm{g} / \mathrm{mL}$ NPBD for $24 \mathrm{~h}$ in MHB and 1\% DMSO, Table S1: Physico-chemical characteristics of NPBD (nitropropenyl benzodioxole), Table S2: NPBD and NPFB inhibition of the enzymic activity of human PTP1B and CD45 and bacterial Yop, Table S3: Serum levels of Compound (1) in the rat following single oral dosing, Table S4: Pharmacokinetic Parameters of Compound (1), Table S5: NPBD selective inhibition of NSCLC cell line A549 using SRB cytotoxicity assay, Table S6: Susceptibility of test strains to Ciprofloxacin, Table S7: MIC of NPBD (mg/L) against representative clinical strains, Table S8: Antibiotic susceptibility of Staphylococcus aureus clinical strains, Table S9: Antibiotic susceptibility of Enterococcus faecalis clinical strains, Table S10: Compound 1 inhibition of growth of Mycobacterium tuberculosis, Table S11: NPBD and HC1 bind to human serum albumin (HSA), Table S12: Effect of plasma on MIC for NPBD against Gram-positive bacteria in MHB, Table S13: MIC for NPBD against laboratory strains with $\log _{10}$ increases in cell density to determine the MIC-cell density relationship. References [61-69] are cited in the supplementary materials.

Author Contributions: Conceptualization, G.N.; Data curation, K.W.; Formal analysis, K.W. and G.N.; Funding acquisition, G.N.; Investigation, K.W., G.N. and H.C.; Methodology, K.W., G.N. and H.C.; Project administration, G.N.; Resources, K.W.; Supervision, G.N.; Validation, K.W., G.N. and H.C.; Visualization, K.W.; Writing—original draft, K.W. and G.N.; Writing—review \& editing, K.W., G.N. and H.C. All authors have read and agreed to the published version of the manuscript.

Funding: This research was supported by RMIT research grants and by Biodiem Ltd.

Data Availability Statement: Data is contained within the article or Supplementary Material.

Acknowledgments: Thu Nguyen provided expert technical assistance for microbial assays performed at RMIT University.

Conflicts of Interest: The funders had no role in the design of the study; in the collection, analyses, or interpretation of data; in the writing of the manuscript, or in the decision to publish the results.

\section{References}

1. Cheng, H.-C.; Qi, R.Z.; Paudel, H.; Zhu, H.-J. Regulation and Function of Protein Kinases and Phosphatases. Enzym. Res. 2011, 2011, 794089. [CrossRef]

2. Tonks, N.K. Protein tyrosine phosphatases-From housekeeping enzymes to master regulators of signal transduction. FEBS J. 2012, 280, 346-378. [CrossRef]

3. Mijakovic, I.; Grangeasse, C.; Turgay, K. Exploring the diversity of protein modifications: Special bacterial phosphorylation systems. FEMS Microbiol. Rev. 2016, 40, 398-417. [CrossRef] [PubMed]

4. Shi, L.; Ji, B.; Kolar-Znika, L.; Boskovic, A.; Jadeau, F.; Combet, C.; Grangeasse, C.; Franjević, D.; Talla, E.; Mijakovic, I. Evolution of Bacterial Protein-Tyrosine Kinases and Their Relaxed Specificity Toward Substrates. Genome Biol. Evol. 2014, 6, 800-817. [CrossRef]

5. Dustin, C.M.; E Heppner, D.; Lin, M.-C.J.; van der Vliet, A. Redox regulation of tyrosine kinase signalling: More than meets the eye. J. Biochem. 2020, 167, 151-163. [CrossRef] [PubMed]

6. Hallenbeck, K.; Turner, D.M.; Renslo, A.R.; Arkin, M.R. Targeting Non-Catalytic Cysteine Residues through Structure-Guided Drug Discovery. Curr. Top. Med. Chem. 2016, 17, 4-15. [CrossRef] [PubMed]

7. Ulrich, K.; Jakob, U. The role of thiols in antioxidant systems. Free. Radic. Biol. Med. 2019, 140, 14-27. [CrossRef]

8. Sajid, A.; Arora, G.; Singhal, A.; Kalia, V.C.; Singh, Y. Protein Phosphatases of Pathogenic Bacteria: Role in Physiology and Virulence. Anпu. Rev. Microbiol. 2015, 69, 527-547. [CrossRef] [PubMed] 
9. Garcia, T.G.; Poncet, S.; Derouiche, A.; Shi, L.; Mijakovic, I.; Noirot-Gros, M.-F. Role of Protein Phosphorylation in the Regulation of Cell Cycle and DNA-Related Processes in Bacteria. Front. Microbiol. 2016, 7, 184. [CrossRef]

10. Yagüe, P.; Gonzalez-Quiñonez, N.; Fernández-García, G.; Alonso-Fernández, S.; Manteca, A. Goals and Challenges in Bacterial Phosphoproteomics. Int. J. Mol. Sci. 2019, 20, 5678. [CrossRef]

11. Park, J.; Pei, D. Trans- $\beta$-Nitrostyrene Derivatives as Slow-Binding Inhibitors of Protein Tyrosine Phosphatases. Biochemistry 2004 43, 15014-15021. [CrossRef] [PubMed]

12. White, K.S.; Nicoletti, G.; Borland, R. Nitropropenyl Benzodioxole, an Anti-Infective Agent with Action as a Protein Tyrosine Phosphatase Inhibitor. Open Med. Chem. J. 2014, 8, 1-16. [CrossRef] [PubMed]

13. Alfarisi, S.; Santoso, M.; Kristanti, A.N.; Siswanto, I.; Puspaningsih, N.N.T. Synthesis, Antimicrobial Study, and Molecular Docking Simulation of 3,4-Dimethoxy- $\beta$-Nitrostyrene Derivatives as Candidate PTP1B Inhibitor. Sci. Pharm. 2020, 88, 37. [CrossRef]

14. Berner, O.M.; Tedeschi, L.; Enders, D. Asymmetric michael additions to nitroalkenes. Eur. J. Org. Chem. 2002, $2002,1877-1894$. [CrossRef]

15. Nicoletti, G.; Cornell, H.J.; Hügel, H.M.; White, K.S.; Nguyen, T.; Zalizniak, L.; Nugegoda, D. Synthesis and Antimicrobial Activity of Nitroalkenyl Arenes. Anti-Infect. Agents 2013, 11, 179-191. [CrossRef]

16. Cornell, H.; Nguyen, T.; Nicoletti, G.; Jackson, N.; Hügel, H. Comparisons of Halogenated $\beta$-Nitrostyrenes as Antimicrobial Agents. Appl. Sci. 2014, 4, 380-389. [CrossRef]

17. Qiu, W.; Liu, X.; Yang, F.; Li, R.; Xiong, Y.; Fu, C.; Li, G.; Liu, S.; Zheng, C. Single and joint toxic effects of four antibiotics on some metabolic pathways of zebrafish (Danio rerio) larvae. Sci. Total Environ. 2020, 716, 137062. [CrossRef]

18. Nicoletti, A.; White, K. Protein tyrosine phosphatase modulators. WO/2008/061308, 29 May 2008.

19. O'Hara, C.M.; Brenner, F.W.; Miller, J.M. Classification, Identification, and Clinical Significance of Proteus, Providencia, and Morganella. Clin. Microbiol. Rev. 2000, 13, 534-546. [CrossRef]

20. Blanco, P.; Hernando-Amado, S.; Reales-Calderon, J.A.; Corona, F.; Lira, F.; Alcalde-Rico, M.; Bernardini, A.; Sanchez, M.B.; Martinez, J.L. Bacterial Multidrug Efflux Pumps: Much More Than Antibiotic Resistance Determinants. Microorganisms 2016, 4, 14. [CrossRef] [PubMed]

21. Harms, A.; Maisonneuve, E.; Gerdes, K. Mechanisms of bacterial persistence during stress and antibiotic exposure. Science 2016, 354, aaf4268. [CrossRef]

22. Römling, U.; Galperin, M.Y.; Gomelsky, M. Cyclic di-GMP: The First 25 Years of a Universal Bacterial Second Messenger. Microbiol. Mol. Biol. Rev. 2013, 77, 1-52. [CrossRef] [PubMed]

23. Gannoun-Zaki, L.; Pätzold, L.; Huc-Brandt, S.; Baronian, G.; Elhawy, M.I.; Gaupp, R.; Martin, M.; Blanc-Potard, A.-B.; Letourneur F.; Bischoff, M.; et al. PtpA, a secreted tyrosine phosphatase from Staphylococcus aureus, contributes to virulence and interacts with coronin-1A during infection. J. Biol. Chem. 2018, 293, 15569-15580. [CrossRef] [PubMed]

24. Musumeci, L.; Bongiorni, C.; Tautz, L.; Edwards, R.A.; Osterman, A.; Perego, M.; Mustelin, T.; Bottini, N. Low-Molecular-Weight Protein Tyrosine Phosphatases of Bacillus subtilis. J. Bacteriol. 2005, 187, 4945-4956. [CrossRef]

25. Petranovic, D.; Michelsen, O.; Zahradka, K.; Silva, C.; Petranovic, M.; Jensen, P.R.; Mijakovic, I. Bacillus subtilis strain deficient for the protein-tyrosine kinase PtkA exhibits impaired DNA replication. Mol. Microbiol. 2007, 63, 1797-1805. [CrossRef]

26. Palmer, K.L.; Godfrey, P.; Griggs, A.; Kos, V.N.; Zucker, J.; Desjardins, C.; Cerqueira, G.; Gevers, D.; Walker, S.; Wortman, J.; et al. Comparative Genomics of Enterococci: Variation in Enterococcus faecalis, Clade Structure in E. faecium, and Defining Characteristics of E. gallinarum and E. casseliflavus. mBio 2012, 3, e00318-11. [CrossRef] [PubMed]

27. Ahmad, Z.; Harvey, R.M.; Paton, J.C.; Standish, A.J.; Morona, R. Role of Streptococcus pneumoniae OM001 operon in capsular polysaccharide production, virulence and survival in human saliva. PLoS ONE 2018, 13, e0190402. [CrossRef]

28. Eshi, L.; Epigeonneau, N.; Eventroux, M.; Ederouiche, A.; Bidnenko, V.; Mijakovic, I.; Noirot-Gros, M.-F. Protein-tyrosine phosphorylation interaction network in Bacillus subtilis reveals new substrates, kinase activators and kinase cross-talk. Front. Microbiol. 2014, 5, 538. [CrossRef]

29. Mijakovic, I.; Petranovic, D.; Macek, B.; Cepo, T.; Mann, M.; Davies, J.; Jensen, P.R.; Vujaklija, D. Bacterial single-stranded DNA-binding proteins are phosphorylated on tyrosine. Nucleic Acids Res. 2006, 34, 1588-1596. [CrossRef]

30. Derouiche, A.; Shi, L.; Bidnenko, V.; Ventroux, M.; Pigonneau, N.; Franz-Wachtel, M.; Kalantari, A.; Nessler, S.; Noirot-Gros, M.; Mijakovic, I. Bacillus subtilis SalA is a phosphorylation-dependent transcription regulator that represses $s c o C$ and activates the production of the exoprotease AprE. Mol. Microbiol. 2015, 97, 1195-1208. [CrossRef]

31. Ge, R.; Shan, W. Bacterial Phosphoproteomic Analysis Reveals the Correlation between Protein Phosphorylation and Bacterial Pathogenicity. Genom. Proteom. Bioinform. 2011, 9, 119-127. [CrossRef]

32. Karthik, M.; Meenakshi, S.; Munavar, M. Unveiling the molecular basis for pleiotropy in selected rif mutants of Escherichia coli: Possible role for Tyrosine in the Rif binding pocket and fast movement of RNA polymerase. Gene 2019, 713, 143951. [CrossRef]

33. Pan, X.; Chen, X.; Su, X.; Feng, Y.; Tao, Y.; Dong, Z. Involvement of SpoVG in hemolysis caused by Bacillus subtilis. Biochem. Biophys. Res. Commun. 2014, 443, 899-904. [CrossRef] [PubMed]

34. Schulthess, B.; Meier, S.; Homerova, D.; Goerke, C.; Wolz, C.; Kormanec, J.; Berger-Bächi, B.; Bischoff, M. Functional Characterization of the $\sigma$ B -Dependent yabJ-SpoVG Operon in Staphylococcus aureus: Role in Methicillin and Glycopeptide Resistance. Antimicrob. Agents Chemother. 2009, 53, 1832-1839. [CrossRef] 
35. Chatterjee, A.; Pandey, S.; Dhamija, E.; Jaiswal, S.; Yabaji, S.; Srivastava, K.K. ATP synthase, an essential enzyme in growth and multiplication is modulated by protein tyrosine phosphatase in Mycobacterium tuberculosis H37Ra. Biochimie 2019, 165, 156-160. [CrossRef]

36. Tyagi, P.; Dharmaraja, A.T.; Bhaskar, A.; Chakrapani, H.; Singh, A. Mycobacterium tuberculosis has diminished capacity to counteract redox stress induced by elevated levels of endogenous superoxide. Free. Radic. Biol. Med. 2015, 84, 344-354. [CrossRef] [PubMed]

37. Manicheva, O.A.; Vishnevskiı̌, B.I.; Miakotina, E.N. Accelerated determination of the Mycobacterium tuberculosis drug re-sistance with a semiliquid culture medium. Klin. Lab. Diagn. 2003, 7, 50-52.

38. Zeitlinger, M.A.; Derendorf, H.; Mouton, J.W.; Cars, O.; Craig, W.A.; Andes, D.; Theuretzbacher, U. Protein Binding: Do We Ever Learn? Antimicrob. Agents Chemother. 2011, 55, 3067-3074. [CrossRef] [PubMed]

39. Imber, M.; Pietrzyk-Brzezinska, A.J.; Antelmann, H. Redox regulation by reversible protein S-thiolation in Gram-positive bacteria. Redox Biol. 2019, 20, 130-145. [CrossRef]

40. Mouton, J.W.; Vinks, A. Pharmacokinetic/Pharmacodynamic Modelling of Antibacterials in Vitro and In Vivo Using Bacterial Growth and Kill Kinetics. Clin. Pharmacokinet. 2005, 44, 201-210. [CrossRef] [PubMed]

41. Fisher, R.A.; Gollan, B.; Helaine, S. Persistent bacterial infections and persister cells. Nat. Rev. Genet. 2017, 15, 453-464. [CrossRef]

42. McCall, I.C.; Shah, N.; Govindan, A.; Baquero, F.; Levin, B.R. Antibiotic Killing of Diversely Generated Populations of Nonreplicating Bacteria. Antimicrob. Agents Chemother. 2019, 63, e02360-18. [CrossRef]

43. Odds, F.C. Synergy, antagonism, and what the chequerboard puts between them. J. Antimicrob. Chemother. 2003, 52, 1. [CrossRef]

44. Munita, J.M.; Arias, C.A. Mechanisms of Antibiotic Resistance. In Virulence Mechanisms of Bacterial Pathogens; Kudva, I.T., Cornick, N.A., Plummer, P.J., Zhang, Q., Nicholson, T.L., Bannantine, J.P., Bellaire, B.H., Eds.; ASM Press: Washington, DC, USA, 2016; pp. 481-511.

45. Meletiadis, J.; Pournaras, S.; Roilides, E.; Walsh, T.J. Defining Fractional Inhibitory Concentration Index Cutoffs for Additive Interactions Based on Self-Drug Additive Combinations, Monte Carlo Simulation Analysis, and In Vitro-In Vivo Correlation Data for Antifungal Drug Combinations against Aspergillus fumigatus. Antimicrob. Agents Chemother. 2010, 54, 602-609. [CrossRef] [PubMed]

46. Ocampo, P.S.; Lázár, V.; Papp, B.; Arnoldini, M.; Wiesch, P.A.Z.; Busa-Fekete, R.; Fekete, G.; Pál, C.; Ackermann, M.; Bonhoeffer, S. Antagonism between Bacteriostatic and Bactericidal Antibiotics Is Prevalent. Antimicrob. Agents Chemother. 2014, 58, 4573-4582. [CrossRef]

47. Chukwudi, C.U. rRNA Binding Sites and the Molecular Mechanism of Action of the Tetracyclines. Antimicrob. Agents Chemother. 2016, 60, 4433-4441. [CrossRef] [PubMed]

48. Belenky, P.; Ye, J.D.; Porter, C.B.; Cohen, N.R.; Lobritz, M.A.; Ferrante, T.; Jain, S.; Korry, B.J.; Schwarz, E.G.; Walker, G.C.; et al. Bactericidal Antibiotics Induce Toxic Metabolic Perturbations that Lead to Cellular Damage. Cell Rep. 2015, 13, 968-980. [CrossRef] [PubMed]

49. Coulson, G.B.; Johnson, B.K.; Zheng, H.; Colvin, C.J.; Fillinger, R.J.; Haiderer, E.R.; Hammer, N.D.; Abramovitch, R.B. Targeting Mycobacterium tuberculosis Sensitivity to Thiol Stress at Acidic pH Kills the Bacterium and Potentiates Antibiotics. Cell Chem. Biol. 2017, 24, 993-1004.e4. [CrossRef] [PubMed]

50. Wang, Y.; Li, X.; Jiang, L.; Han, W.; Xie, X.; Jin, Y.; He, X.; Wu, R. Novel Mutation Sites in the Development of VancomycinIntermediate Resistance in Staphylococcus aureus. Front. Microbiol. 2017, 7, 2163. [CrossRef] [PubMed]

51. Watanabe, Y.; Cui, L.; Katayama, Y.; Kozue, K.; Hiramatsu, K. Impact of rpoB Mutations on Reduced Vancomycin Susceptibility in Staphylococcus aureus. J. Clin. Microbiol. 2011, 49, 2680-2684. [CrossRef]

52. Barriere, S.L. Clinical, economic and societal impact of antibiotic resistance. Expert Opin. Pharmacother. 2014, 16, 151-153. [CrossRef]

53. Lazo, J.S.; McQueeney, K.E.; Sharlow, E.R. New Approaches to Difficult Drug Targets: The Phosphatase Story. SLAS Discov. Adv. Life Sci. RED 2017, 22, 1071-1083. [CrossRef]

54. Ruddraraju, K.V.; Zhang, Z.-Y. Covalent inhibition of protein tyrosine phosphatases. Mol. BioSyst. 2017, 13, 1257-1279. [CrossRef]

55. Stanford, S.M.; Bottini, N. Targeting Tyrosine Phosphatases: Time to End the Stigma. Trends Pharmacol. Sci. 2017, 38, 524-540. [CrossRef] [PubMed]

56. Bocian-Ostrzycka, K.M.; Grzeszczuk, M.J.; Banaś, A.M.; Jagusztyn-Krynicka, E.K. Bacterial thiol oxidoreductases-From basic research to new antibacterial strategies. Appl. Microbiol. Biotechnol. 2017, 101, 3977-3989. [CrossRef] [PubMed]

57. Kim, J.H.; Faria, N.C.G.; Martins, M.D.L.; Chan, K.L.; Campbell, B.C. Enhancement of Antimycotic Activity of Amphotericin B by Targeting the Oxidative Stress Response of Candida and Cryptococcus with Natural Dihydroxybenzaldehydes. Front. Microbiol. 2012, 3, 261. [CrossRef] [PubMed]

58. Tavangar, F.; Sepehri, H.; Jazi, M.S.; Asadi, J. Amphotericin B potentiates the anticancer activity of doxorubicin on the MCF-7 breast cancer cells. J. Chem. Biol. 2017, 10, 143-150. [CrossRef]

59. CLSI. Methods for Antimicrobial Susceptibility Testing of Anaerobic Bacteria; Approved standard M11; Clinical and Laboratory Standards Institute: Wayne, PA, USA, 2007.

60. CLSI. Methods for Dilution Antimicrobial Susceptibility Tests for Bacteria that Grow Aerobically; CLSI standard M07; Clinical and Laboratory Standards Institute: Wayne, PA, USA, 2009. 
61. Skehan, P.; Storeng, R.; Scudiero, D.; Monks, A.; McMahon, J.; Vistica, D.; Warren, J.T.; Bokesch, H.; Kenney, S.; Boyd, M.R. New Colorimetric Cytotoxicity Assay for Anticancer-Drug Screening. J. Natl. Cancer Inst. 1990, 82, 1107-1112. [CrossRef]

62. Denisenko, P.P.; Sapronov, N.S.; Tarasenko, A.A. Antimicrobial and radioprotective compounds. WO/2002/102789, 14 June 2002.

63. Nguyen, L. Antibiotic resistance mechanisms in M. tuberculosis: an update. Arch. Toxicol. 2016, 90, 1585-1604. [CrossRef]

64. Bach, H.; Wong, D.; Av-Gay, Y. Mycobacterium tuberculosis PtkA is a novel protein tyrosine kinase whose substrate is PtpA. Biochem. J. 2009, 420, 155-162. [CrossRef]

65. Beresford, N.J.; Mulhearn, D.; Szczepankiewicz, B.; Liu, G.; Johnson, M.E.; Fordham-Skelton, A.; Abad-Zapatero, C.; Cavet, J.S.; Tabernero, L. Inhibition of MptpB phosphatase from Mycobacterium tuberculosis impairs mycobacterial survival in macrophages. J. Anitmicrob. Chemother. 2009, 63, 928-936. [CrossRef]

66. Beer, J.; Wagner, C.C.; Zeitlinger, M. Protein Binding of Antimicrobials: Methods for Quantification and for Investigation of its Impact on Bacterial Killing. AAPS J. 2009, 11, 1. [CrossRef]

67. Eng, R.H.; Cherubin, C.; Smith, S.M.; Buccini, F. Inoculum effect of beta-lactam antibiotics on Enterobacteriaceae. Antimicrob. Agents Chemother. 1985, 28, 601-606. [CrossRef] [PubMed]

68. Salas, J.R.; Jaberi-Douraki, M.; Wen, X.; Volkova, V.V. Mathematical modeling of the 'inoculum effect': Six applicable models and the MIC advancement point concept. FEMS Microbiol. Lett. 2020, 367, fnaa012. [CrossRef] [PubMed]

69. Wu, N.; Chen, B.Y.; Tian, S.F.; Chu, Y.Z. The inoculum effect of antibiotics against CTX-M-extended-spectrum $\beta$-lactamaseproducing Escherichia coli. Ann. Clin. Microbiol. Antimicrob. 2014, 13, 45. [CrossRef] [PubMed] 